\title{
P-16
}

\section{Pyhtochemical Studies on Resveratrol from Dipterocarpus Crinitus as Damping Off Disease Agent}

\author{
Wan Zuraida Wan Mohd Zain ${ }^{1, *}$, Norizan Ahmat $^{1}$, NorHazana Norizan ${ }^{1}$, Arnt Win ${ }^{2}$, Yoshiaki \\ Takaya $^{3}$ and Neni Kartini Che Ramli ${ }^{4}$ \\ ${ }^{I}$ Faculty of Applied Sciences, Universiti Teknologi MARA, 40450 Shah Alam, Malaysia ${ }^{2}$ Department of chemistry, \\ University of Mandalay, Myanmar; ${ }^{3}$ Faculty of Pharmacy, Meijo university, Nagoya, Japan; ${ }^{4}$ Faculty of Agriculture, \\ Universiti Teknologi MARA, 26400, Jengka, Pahang, Malaysia; E-mail: wanzuraida@pahang.uitm.edu.my
}

Dipterocarpus crinitus (Dipterocarpaceae) known as "keruing mempelas" by the local is widely distributed in Johor and Pahang [1]. The stem bark of Dipterocarpus crinitus which was collected from Jengka, Pahang has been extracted in methanol by cold immersion method. The extract was fractionated by column chromatography to afford 6 fractions (DC1- DC6). Fraction DC 3 and 4 were further purified by column chromatography and led to the isolation of 5 oligomer resveratrol: $\alpha$-Viniferin (1), $\varepsilon$-viniferine (2), Hopeaphenol (3), isohopehenol (4) and laevifonol (5). The structure of the compounds were confirmed by one and two-dimensional NMR analyses and comparison with previous data [2]. The polyphenolic compounds which are known as phytoalexin were further investigated for antioxidant and damping off disease agent. The antioxidant indicated lower scavenging activity (DPPH) compared to BHT and ascorbic acid with percent scavenging activity of between $46.6 \%$ to $15.8 \%$. However the compounds revealed strong inhibition zone against four genus of fungal i.e Rhizoctonia solani, Fusarium $s p$, Pythium sp. and Phytophthora sp., the pathogens of vegetables. In this work we have proved that the stem bark of this timber which is rich in phytoalexine (the antifungal substance) and are not used in timber industry has great value in combating damping off disease. In Malaysia, wood dust have been commercialized as antifungal and fertilizer agent [3].

Keywords: Dipterocarpaceae, Dipterocarpus crinitus, resveratrol, antifungal.

\section{REFERENCES}

[1] Symington CF. Foresters' manual of dipterocarps. Kuala Lumpur: Uni Malaya Publication 1974; pp. 1-356.

[2] Muhtadi, Hakim EH, Juliawaty LD, et al. Cytotoxic resveratrol oligomers from the tree bark of Dipterocarpus hasseltii. Fitoterapia 2006; 77: 550-5.

[3] Info Pertanian. Pegaga-herba difokus dalam program transformasi ekonomi negara 2012; 13: 57-8. 